\title{
DAMPAK PEMEKARAN KABUPATEN PANGANDARAN TERHADAP POTENSI BUDAYA DAN PARIWISATA ALAM KABUPATEN CIAMIS
}

\author{
Wulan Sondarika ${ }^{1 \mathrm{a}}$, Dewi Ratih ${ }^{\mathrm{b}}$, Aan Suryana \\ a, b, cDosen Program Studi Pendidikan Sejarah FKIP-Universitas Galuh Ciamis \\ Jl. R. E. Martadinata No. 150 Ciamis, 46274 Jawa Barat
}

\begin{abstract}
ABSTRAK
Pemekaran suatu daerah tentu akan berdampak pada segala aspek, aspek budaya dan pariwisata bagi Kabupaten Ciamis. Tujuan utama dari penulisan karya ilmiah ini yaitu untuk menganalisis pemekaran Daerah Pangandaran; aspek budaya dan aspek pariwisata. Metode penelitian ini menggunakan pendekatan kualitatif. Hasil penelitian potensi budaya kabupaten Ciamis sebelum terjadinya pemekaran kabupaten Pangandaran yaitu, ronggeng gunung, Bebegig Sukamantri, ronggeng amen, debus Panjalu, wayang landung, dan sebagainya. Sedangkan untuk pariwisata alam yang memberikan pemasukan paling besar bagi PAD kabupaten Ciamis yaitu wisata alam pantai Pangandaran. Potensi budaya dan pariwisata alam kabupaten Ciamis setelah terjadinya pemekaran kabupaten Pangandaran mengalami perubahan, yaitu belum jelasnya kesenian ronggeng gunung dalam hal kepemilikan, Sedangkan untuk pariwisata alam, kabupaten Ciamis kehilangan wisata alam pantai Pangandaran yang memberikan pemasukan paling besarbagi PAD kabupaten Ciamis. Sedangkan, dampak pemekaran kabupaten Pangandaran yang sangat besar dirasakan adalah dalam hal pariwisata alam, karena dengan terlepasnya Pangandaran, kabupaten Ciamis kehilangan PAD sampai $85 \%$ dan apabila diuangkan mencapai 6 miliar.
\end{abstract}

Kata Kunci: Pemekaran, Budaya, dan Pariwisata

\begin{abstract}
Expansion of a region will certainly impact on all aspects, cultural and tourism aspects for the District of Ciamis. The main purpose of the writing of this scientific paper is to analyze the expansion of Pangandaran Region; cultural aspects and aspects of tourism. The method used hearts singer research is using qualitative approach. The results of the research potential of cultural Ciamis district before the onset of Pangandaran regencies, namely, Ronggeng Mountains, Bebegig Sukamantri, Ronggeng Amin, Debus Panjalu, Landung Puppet, and so forth. As for the nature tourism review that brings in big fence Revenue Share (PAD) Ciamis District Pangandaran Beach is a natural attraction. The potential of cultural and natural tourism Ciamis District taxable income of the province was split Pangandaran Regency unchanged, ie unclear arts ronggeng mountain hearts ownership, while for a review of natural tourism, Ciamis district Loss of natural attractions Pangandaran That gives entry fence big Revenue Share PAD (PAD) Ciamis District. Meanwhile, the impact of the expansion Pangandaran Regency most big hearts felt is eco-tourism thing, because with the release of Pangandaran, Ciamis Regency Lost Revenue (PAD) to 85\% and when cashed reached 6 billion.
\end{abstract}

Keywords: Redistricting, Culture, and Tourism

\section{PENDAHULUAN}

Kabupaten Ciamis merupakan sebuah kabupaten yang terletak di daerah provinsi Jawa Barat, dengan ibu kotanya terletak di Ciamis kota. Kabupaten Ciamis terletak dibagian tenggara Jawa Barat, berbatasan dengan Kabupaten Majalengka dan Kabupaten Kuningan utara, Kabupaten Cilacap (Jawa Tengah) dan Kota Banjar di timur, serta Kota Tasikmalaya.

\footnotetext{
${ }^{1}$ Penulis Koresponden

E-mail address: wulansondarika@gmail.com doi:
} 
Pada tahun 2013 kabupaten Ciamis mengalami perubahan dalam jumlah pemerintahan, yaitu terdiri atas 26 kecamatan, 258 desa dan 7 keluruhan, serta terdiri dari 2.910 RW dan 9.123 RT. Perubahan ini terjadi karena adanya pemekaran Kabupaten Pangandaran (BPS Kabupaten Ciamis, 2013). Selain berpengaruh pada jumlah pemerintahan, pemekaran Kabupaten Pangandaran pun memberikan pengaruh yang signifikan bagi potensi pariwisata alam yaitu, kabupaten Ciamis kehilangan pantai Pangandaran yang merupakan asset besar bagi pendapatan daerah. Dampak lain yang lebih signifikan dari adanya pemekaran kabupaten Pangandaran adalah kabupaten Ciamis kehilangan salah satu icon potensi pariwisata budaya yang merupakan ciri khas dari kabupaten ini, yaitu ronggeng gunung. Ronggeng Gunung merupakan hiburan bagi masyarakat disekitar pegunungan, disajikan sebagai hiburan pelepas lelah manakala mereka selesai menanam padi atau sehabis panen. Untuk pelepas lelah dan disajikan pada waktu malam hari.

Menurut Dadan Wildan, sesuai dengan sebutannya, Ronggeng Gunung merupakan pertunjukkan yang menampilkan seorang penari sekaligus penyanyi yang berasal dari gunung. Penyajian ronggeng gunung dimainkan dengan alat musik sederhana yang terdiri dari satu kendang, tiga ketuk dan satu gong. Dalam penyajiannya, Ronggeng gunung lebih dpusattkan pada kaki sang penari. Penari biasanya menari secara bergerombol, membentuk suatu lingkaran searah dengan jarum jam yang mengelilingi ronggengnya. Pada lagu tertentu menari dengan berkerudung sarung atau iket (Dinas Pendidikan dan Kebudayaan Kabupaten Ciamis, 2014).

Melihat kondisi di atas, maka pemerintah harus mencari alternatif lain untuk mengembangkan potensi unggulan yang ada di Kabupaten Ciamis. Salah satunya dengan mengembangkan potensi budaya yang cukup potensial, sehingga potensi tersebut dapat menjadi icon baru bagi Kabupaten Ciamis. Selain itu pemerintah kabupaten Ciamis dapat mengembangkan ekonomi kreatif berbasis kearifan lokal. Hal ini sesuai dengan apa yang diterangkan dalam Peraturan Presiden Nomor 28 Tahun 2008 tentang Kebijakan Industri Nasional, dimana Presiden mengajak untuk mengembangkan produk ekonomi yang berbasis seni budaya dan kerajinan, berbasis pada warisan, tradisi dan adat, sebagai titik tolak meningkatkan daya saing dalam pengembangan ekonomi kreatif, sehingga dengan adanya pemekaran kabupaten Pangandaran tidak memberikan dampak yang begitu besar bagi perkembangan kabupaten Ciamis.

\section{METODE PENELITIAN}

Metode dalam penelitian ini yaitu menggunakan pendekatan kualitatif.Penelitian kualitatif merupakan metode-metode untuk mengekplorasi dan memahami makna yang oleh sejumlah individu atau sekelompok orang dianggap berasal dari masalah sosial atau kemanusiaan (Creswell, 2010: 4). Keberhasilan suatu penelitian sangat ditentukan oleh kemampuan memilih serta menggunakan metode. Metode penelitian dapat diartikan sebagai cara yang digunakan peneliti dalam proses pemecahan masalah, sehingga dengan cara itulah tujuan yang dihendaki peneliti dapat tercapai.

Sehubungan dengan itu Hasan $(2003,21)$ menjelaskan bahwa "Metode penelitian adalah tata cara bagaimana suatu penelitian dilaksanakan". Sementara itu menurut Poerwadarminta (1991: 649)menjelaskan bahwa "Metode adalah suatu cara yang lebih dipikirkan dan dapat memberikan arah serta petunjuk melakukan suatu penelitian".

Seperti yang diungkapkan oleh Lincoln dan Guba (1985:39), lebih suka menggunakan istilah naturalistic inquiryoleh karena ciri yang menonjol dari penelitian ini adalah cara pengamatan dan pengumpulan datanya dilakukan dalam latar/setting alamiah, artinya tanpa memanipulasi subjek yang diteliti (sebagaimana adanya/natur), peneliti juga dapat dimanfaatkan sebagai instrumen yang lebih luwes untuk dapat memaknai realitas dan interaksi di lapangan (Mulyana, 2010:160).

Pendekatan naturalistik termasuk kualitatif yang ditandai dengan induktif, konstruktif, dan subjektif. Creswell (1998: 15) berpendapat bahwa:

"Penelitian kualitatif naturalistik yaitu penelitian pemahaman berdasarkan tradisi penelitian metodologi yang beda dengan yang lain dan jelas yang menguraikan secara detail problema sosial atau manusia itu sendiri. Penelitimenggambarkan sesuatu yang kompleks, menganalisis setiap katakata, melaporkan secara detil dari setiap 
pandangan-pandangan para informasi dan melakukan studi dalam setting yang alami”.

\section{PEMBAHASAN}

\section{Potensi Budaya Ciamis sebelum pemekaran Pangandaran}

\section{Kesenian Ronggeng Buhun}

Menurut Dadan Wildan, sesuai dengan sebutannya Ronggeng Gunung ini merupakan pertunjukkan tarian tradisional yang dibawakan oleh seorang penari perempuan sekaligus penyanyi yang berasal dari gunung atau daerah. Penyajian Ronggeng Gunung dimainkan dengan alat musik sederhana yang terdiri dari satu kendang, tiga ketuk dan satu gong. Dalam kesenian Ronggeng gunung ini mempunyai lagulagu khas. Laggu-lagu tersebut berjumlah delapan belas lagu yang harus dinyanyikan dalam setiap pertunjukan ronggeng gunung. Tarian tradisional ini dipustkan pada kaki seorang penari yang dibawakan secara serentak, dan apabila salah seorang penari melakukan kesalahan, maka penari tersebut akan terinjak oleh penari yang lain.. Penari biasanya menari secara bergerombolan, membentuk lingkaran searah dengan jarum jam dan mengelilingii ronggengnya. Pada lagu tertentu menari dengan berkerudung sarung atau iket (Wildan, 2005: 130).

Ronggeng Gunung merupakan hiburan bagi masyarakat disekitar pegunungan, disajikan sebagai hiburan pelepas lelah manakala mereka selesai menanam padi atau sehabis panen. Untuk pelepas lelah dan disajikan pada waktu malam hari (Sejarah singkat Ronggeng Gunung, 2012:).

Namun selain untuk hiburan masyarakat pegunungan Ronggeng juga biasa ditampilkan dalam acara-acara penjamuan makan malam di rumah kediaman para Bupati. Beberapa gadis penari ditampilkan dan para Bupati serta Adipati menari dengan masing-masing penari dengan diiringi suara musik yaitu gamelan yang berlanjut sampai larut malam (Stockdale, 2014: 192).

Penari utamanya beberepa perempuan yang dilengkapi dengan sebuah selendang. Fungsi selendang atau kain yang disimpan dileher, berfungsi untuk kelengkapan dalam sebuah tarian ronggeng. Selain berfungsi untuk kelengkapan juga dapat digunakan untuk "menggaet" lawan dengan cara mengalungkan selendang ke lehernya. Selendang tersebut biasanya berwarna mencolok seperti warna kuning tanda keagungan (kebesaran) ataupun warna merah sebagai warna keberanian. Biasanya menyelendangkan lesendang dilakukan pada saat menyambut tamu besar, warna merah dan biru. Warna tersebut biasanya digunakan pada acara hiburan. Sedangkan peralatan musik yang digunakan untuk mengiringi tari Ronggeng Gunung adalah tiga buah ketuk, yaitu kendang, kenong dan goong (wawancara dengan Bi Raspi tanggal 15 Februari 2016).

\section{Kesenian Gondang Buhun}

Gondang Buhun adalah seni tetabuhan (tutunggulan) yang diiringi dengan nyanyian tradisional. Alatnya terdiri dari sebuah lisung (lesung wadah untuk menumbuk padi) dan halu (alu), yang merupakan tempat penumbuk padi. Lesung menghasilkan bunyi-bunyian teratur, bunyian tersebut berasal dari tumbukan alu kedalam bagian lesung maupun bagian luar. Pemain gondang buhun biasanya dibawakan oleh beberapa perempuan yang berjumlah lima sampai tujuh orang. Kesenian tradisional ini terdapat di beberapa wilayah pedesaan di Ciamis. Salah satunya adalah Kampung Kuta, Desa Karangpaniggal, Kecamatan Tambaksari, Kabupaten Ciamis. Mareka yang kini masih bisa Ngagondang diantaranya Enah, Kariah, Anah dan Niti (Dinas Pendidikan dan Kebudayaan Kab.Ciamis, 2014: 31).

Menurut Wawan Dalam Apip Nasihudin gambaran secara umum seni Gondang sebagai salahsatu jenis seni tradisional. Seni menumbuk padi dengan alu serta lesung sebagai alat bunyibunyian guna sarana upacara penghormatan kepada Dewi Sri (dewi padi). Sebutan lain ngagender, ngagendreh, tutunggulan, ngarempung, nutu, ngalesu, ngotrek. Pengertian yang diberikan oleh ahli lain bahwa Gondang berarti seni tradisi menumbuk padi yang biasa dipentaskan oleh para petani atau masyarakat kampung yang penyelenggarakannya di tepi sebuah kolam. Adapun makna dari seni ini adalah sebagai bersyukur kepada Dewi Sri (dewi padi) yang dipercaya penganutnya sebagai pemberi keberkahan kepada petani. Bentuk pementasan dalam seni Gondang dilakukan dilapangan atau arena terbuka, sehingga penonton dapat menyaksikan gerak-gerik para pelaku dari segala arah. Pemain kendang, suling, kecapi dan goong berada disuatu tempat yang sudah disediakan di dalam arena, tentunya berada tidak jauh dari lesung dan para penumbuk padi atau pemain seni Gondang. Kecuali dalam 
seni ini tidak diperlukan pegangan khusus, karena alat berat yang digunakan sebagai pengiring seni ini (lesung) tidak memungkinkan disimpan diatas panggung. Lapangan atau arena yang sebaiknya digunakan adalah lapangan luas yang memiliki kolam, karena lesung ditempatkannya dipinggir kolam, seperti tradisi yang dilakukan para leluhur, tetapi tidakpun tidak menjadi masalah.

Kesenian Gondang Buhun ini terkait dengan beberapa ritus, antara lain ritus Nyi Pohaci Sanghyang Sri (Mapag Sri). Ritus meminta hujan dan sebagai undangan Kenduri. Gondang yang dipentaskan dalam rangka upacara Mapag Sri atau ngampiheun (menyimpan padi ke lumbung) biasanya dilakukan setelah panen usai. Tempatnya dilaksanakan disekitar leuit (lumbung padi). Upacara itu dimulai oleh seorang Punduh (sesepuh upacara) perempuan. Dalam ritual sesepuh berdoa sambil membakar kemenyan, hal ini dianggap sebagai perantara untuk memohon kepada Tuhan yang Maha Kuasa dan mengucapkan rasa syukurnya atas hasil panen yang didapat. Padipun diarak, dimasukkan kedalam lumbung sambil diiringi tutunggulan. Selain itu nyanyian Gondangpun dilantunkan dengan penuh keceriaan (Dinas Pendidikan dan Kabupaten Kab. Ciamis, 2014: 31).

Suara lesungya yang terdengar nyaring sampai jauh, berfungsi sebagai pemberitahuan atau sebagai tanda adanya seseorang yang akan mengadakan kenduri. Suara tutunggulan dan nyanyian-nyamyian itu adalah undangan kepada khalayak ramai untuk hadir dan ikutbersuka cita dengan orang yang punya hajat. Tutunggulan biasanya dilakukan tiga samapi satu minggu kenduri itu dilaksanakan. Pada permainannya dibagi menjadi dua bagian, yakni tutunggulan dan nyanyian. Dalam Gondang buhun memiliki empat jenis tutunggulan, disetiap jenisnya mempunyai irama yang khas. Keempat tutunggulan itu ialah:

1) Galuntang, dimainkan oleh empat atau banyak orang, fungsinya sebagai pembuka dan menutup pertunjukan.

2) Pingping hideung, dibawakan oleh empat orang.

3) Ciganjengan, dimainkan oleh lima orang

4) Angin-anginan, dimainkan oleh tujuh orang

Setiap pemain Gondang mempunyai motif irama dan tumbukannya sendiri. Motif tumbukan atau tabuhan yang berbeda-beda itu kemudian dipadukan sehingga membentuk sebuah komposisi irama. Motif tabuhan tersebut antara lain; turun unggah atau midua, gejog, onjon,titir, kutek, ambruk, tilingting dan dongdo (http://www.disbudpar.jabarprov.go.id)

\section{Kesenian Ronggeng Amen}

Ronggeng Amen awalnya disebut dengan sebutan Ronggeng Ngamen karena biasanya penonton ikut menari bersama Ronggeng. Untuk mengetahui sejarah Ronggeng Amen harus dilihat dari awal munculnya Ronggeng Gunung yang merupakan cikal bakalnya. Berdasarkan sumber yang didapat, kesenian Ronggeng Gunung sudah ada sebelum agama Islam masuk ke Kerajaan Galuh. Menurut cerita rakyat Ciamis terbentuknya seni Ronggeng Gunung merupakan perwujudan dari suatu wangsit atau amanat seorang patih yaitu Patih Kidang Pananjung kepada Dewi Siti Samboja kira-kira abad ke XVI yang merupakan salah seorang puteri Prabu Siliwangi ke-38. Ronggeng Amen yang merupakan seni tradisional khas Ciamis ini banyak ditemui diberbagai daerah Ciamis diantaranya Banjarsari, Padaherang, Kalipucang, Pangandaran, Parigi, Cijulang, Tambaksari hingga ke perbatasan Cilacap Jawa Tengah. Pada daerah-daerah tersebut sebagian masyarakatnya hidup dari sumber daya agraris atau pertanian. Seni Ronggeng Amen lahir ditengah-tengah kultur petani, khususnya di Ciamis dimana masyarakatnya memiliki ikatan yang erat dengan budaya bercocok tanam. Ronggeng berkembang ditengah budaya pertanian karena dahulu Ronggeng kerap dimainkan sebagai bagian dari ritual atau syukuran masyarakat agraris atas berhasilnya panen raya padi. Bahkan dulu Ronggeng dimainkan pada siang hari ditengah sawah, untuk menemani petani yang sedang memanen padi (Kompas, 26 Agustus 2010).

Bapak Asep menuturkan bahwa lebih kurang tahun 1992 muncul kesenian Ronggeng Amen yang merupakan modifikasi dari Ronggeng Gunung, namun penyajian Ronggeng Amen lebih lentur karena karawitan dan lagu disajikan sebagai iringan tarian, dan dalam kesenian ini juga sudah jarang menggunakan lagu-lagu Ronggeng Gunung asli, tetapi mengambil lagu-lagu kekinian terutama lagu Kliningan seperti lagu Daun Hiris yang mengisahkan tentang keindahan alam dan kehidupan desa yang asri. Kesemarakan dan kemeriahan pada pertunjukkan Ronggeng Amen adalah terlibatnya para penonton untuk 
berpartisifasi aktif sebagai peserta nari. Pertunjukkan kesenian ini hampir mirip dengan kesenian rakyat Jawa Barat lainnya seperti Ketuk Tilu, Bajidoran dll (wawancara Bapak Asep tanggal 13 Februari 2016 pimpinan Seni Ronggeng Amen Tambaksari sanggar Surya Gumilang).

Berbeda dengan Ronggeng Gunung yang syarat akan unsur ritual pada malam hari, justru Ronggeng Amen ini lebih menonjolkan unsur hiburan dan bebas dimainkannya baik siang maupun malam. Di Ciamis tepatnya di Kecamatan Tambaksari, Ronggeng Amenpun diminati oleh semua lapisan masyarakat dan semua kalangan, mulai dari anak-anak, orang tua, laki-laki dan perempuan. Penari dalam Ronggeng Amen biasanya berjumlah tiga atau empat penari bahkan bisa mencapai tujuh orang, terutama ketika tampil di pesta pernikahan. Dalam kegiatan menari tetap ada aturannya seperti Ronggeng Gunung pada umumnya, hanya yang membedakannya terdapat didalam musik yang mengiringinya dan dari segi kostum yang dipakainya. Untuk penari Ronggeng memakai kebaya modern dan tidak memakai kain samping yang lilitkan pada tubuh dan tetap menggunakan selendang yang berwarna mencolok. Dan untuk pakaian laki-laki tidak memakai kain sarung seperti pada Ronggeng Gunung (wawancara dengan pa Asep pimpinan seni Ronggeng Amen Tambaksari sanggar Surya Gumilang tanggal 13 Februari 2016).

Alat musik yang digunakan dalam pertunjukkan Ronggeng Amen berbeda dengan alat musik yang digunakan dalam Ronggeng Gunung. Apabila dalam kesenian Ronggeng Gunung hanya menggunakan tiga alat kesenian diantaranya adalah kendang, kenong dan gong berbeda dengan alat musik yang digunakan dalam kesenian Ronggeng Amen diantaranya gamelan dan salendro kliningan (wawancara dengan pa Asep pimpinan seni Ronggeng Amen Tambaksari sanggar Surya Gumilang tanggal 13 Februari 2016).

Dalam Wikipedia menjelaskan bahwa Kliningan merupakan seperangkat gamelan yang berlaras salendro diiringi oleh juru sekar yang terdiri dari Sinden dan Wira Swara. Kliningan juga disebut dengan siku-siku segitiga yang biasa dipukul. Kliningan berasal dari daerah pantai utara Jawa Barat (Karawang, Bekasi, Purwakarta, Indramayu dan Subang). Bentuk Kliningan seperti Gender (alat gamelan Jawa). Seni Kliningan termasuk dalam ragam karawitan Sekar-Gending. Oleh karena itu juru kawih atau sinden memiliki peran yang sangat sentral dalam seni Kliningan. Materi seni Kliningan terdiri dari dua unsur yang menyatu, yaitu juru sekar atau penyanyi dengan juru gending atau pemain musik. Juru sekar biasanya perempuan adan lakilaki. Penyanyi perempuan disebut sinden sedangkan yang laki-laki disebut Wira Swara.

Tugas sinden yaitu hanya menyanyikan lagu-lagu. Dalam membawakan lagu, tiap penyanyi harus mengikuti aturan gending (musik yang mengiringi). Sedangkan alatnya disebut gamelan berlarasnya salendro. Setiap alat musiknya dimainkan oleh satu nayaga yang lakilaki. Pangrawit di Kliningan dipimpin oleh satu orang yang biasanya merangkap sebagai nayaga juga. Yang mengatur disebut Lurah Sekar. Lagu yang disajikan dalam Kliningan utamanya yaitu lagu-lagu khas Kliningan. Lagu-lagunya berupa gabungan dari lagu-lagu tradisi kreasi baru, atau lagu-lagu yang masih diketahui oleh penciptanya, seperti Es Lilin, Sakadang Kuya, Torot Heong, Bubuka Ganda Mekar,Alesan dan sebagainya.

\section{Wayang Landung}

Proses penciptaan wayang landung sudah dimulai sejak tahun 2000. Cikal bakal seni wayang landung adalah pada saat akan dilaksanakannya Pangandaran Kite Festival. Unsur seni rupa wayang golek yang divisualisasikan dengan besar itulah yang kemudian menjadi wayang landung. Sedangkan nama wayang landung diambil dari dedaunan yang dipakai sebagai kostum wayang yang panjang sehingga menutupi pemain di dalamnya yang dalam bahasa Sunda yaitu landung.

Wayang Landung diilhami oleh wayang golek baik itu dari segi struktur dasarnya maupun teknik memainkannya dan diproyeksikan dalam skala besar. Cara memainkan wayang landung hampir sama dengan ondel-ondel dari daerah Betawi. Namun ada beberapa perbedaan yaitu terletak pada gerakannya dimana wayang landung lebih dinamis karena sepasang tangannya diberi tuding sepanjang 1,5 meter sehingga dapat digerakkan oleh pemain seperti halnya wayang golek pada umumnya.

Dalam kesenian wayang landung terdapat beberapa unsur seni didalamnya, yaitu seni musik, seni tari, dan seni rupa. Unsur seni musik terletak pada alat musik yang mengiringinya, unsur seni tari bisa dilihat dari para penari yang mengiringi wayang landung juga orang yang memanggul wayang landung itu sendiri, 
sedangkan unsur seni rupa bisa dilihat dari topeng wayang landung yang menjadi kepala wayang. Unsur-unsur seni tersebut tidak dapat dipisahkan karena merupakan sebuah kesatuan dan saling melengkapi satu sama yang lainnya (Dinas Pendidikan dan Kebudayaan Kab. Ciamis, 2014: 200).

\section{Bebegig}

Bebegig Sukamantri merupakan kesenian tradisional yang berasal dari desa Sukamantri kecamatan Sukamantri kabupaten Ciamis. Dinamakan Bebegig Sukamantri karena hanya terdapat di desa Sukamantri. Bebegig tersebut sagat berbeda dengan orang-orangan sawah yang biasanya petani-petani di Indonesia menggunakannya untuk menakuti burung sawah. Bebegig Sukamantri adalah manusia yang mengenakan topeng berbentuk buta ijo, kepalanya besar, giginya taring, barambut gimbal, tubuhnya berwarna hitam, hidung lancip, matanya melotot ban berwarna macammacam. Bebegig Sukamantri memeliki cirri khas menggunakan atribut, seperti rambut gimbal yang terbuat dari susunan bunga bubuay (kalung kerbau), sedangkan bebeging pada umumnya dibuat mirip boneka menggunakan pohon padi atau sejenisnya, terus dibalut pakaian layaknya manusia yang turun ke sawah difungsikan untuk mengusir hama. Topeng Bebegig yang berbobot hampir $70 \mathrm{~kg}$ didominasi tiga warna yaitu merah, hitam dan hijau yang melambangkan keberanian, ketegasan dan kecintaan terhadap alam. Topeng Bebegig biasanya disemayamkan di astana (makam leluhurnya) disertai doa-doa mohon keselamatan bagi para pemakainya sebelum dipentaskan.

Adapun atribut yang digunaan oleh Bebegig Sukamantri diantaranya:
1) Ijuk
2) Daun waregu
3) Kolotok

Seni Bebegig Sukamantri adalah seni budaya warisan leluhur masyarakat desa Sukamantri yang sangat berharga, ditengah perkembangan kehidupan teknologi, pergeseran nilai yang berpacu dengan era mederisasi masyarakat. Seni Bebegig Sukamantri tampil sebagai seni hiburan yang mampu menghadapi pengaruh negative modernisasi, dengan kesan yang eksklusif, tetapi tetap menjadi symbol jatidiri masyarakat desa Sukamantri yang semakin dinamis (Dinas Pendidikan dan Kebudayaan Kab. Ciamis, 2014: 212).

\section{Debus Panjalu}

Kesenian debus merupakan kesenian turun temurun dan didalamnya menampilkan tarian-tarian dan atraksi-atraksi khas Sunda yang harus dilakukan oleh orang yang sudah mahir.

Persyaratan yang harus ditempuh oleh pemain debus disetiap penampilannya adalah:

a. Melakukan puasa selama 40 hari.

b. Setelah sholat fardu diharuskan membaca basmalah sebanyak-banyaknya.

c. Membaca wirid sebanyak sebanyak sebelas kali

d. Adapun bacaan wiridnya sebagai berikut; "bismillahirohmanirohim"

Inna a'toina kal kautsar fasholli liwali warba

Tulung para wali sakabeh, mangka welas mangki asih

Atine wong sadunia madeleng maring isun, berkahna Lailahailaloh

Muhammadurosululoh

Bismillahirohmanirohim

Bima bayu ongedek agu geni murud mati dening aku

Repsirep atine wong sadunia madeleng maring isun, berkahna

Lailahailaloh Muhammadarosuloloh.

e. Harus yakin dengan apa yang dipelajari dan diamalkan

f. Menjauhi larangan yang telah ditetapkan oleh agama Islam (maling, maen, madon, minum, madat).

Adapun tahapan pertunjukan debus yang biasa ditampilkan:

1) Pembukaan, yaitu pembacaan ayat sholawat dan puji-pujian yang di iringi instrument masik tabuh.

2) Pelaksanaan dzikir kepada Allah dan sholawat kepada Nabi Muhammad sambil di iringi tabuhan music.

3) Beluk, yaitu nyanyian yang dibawakan oleh pendzikir degan suara keras, sambil bersahut-sahut dan di iringi dengan tabuhan.

4) Silat, ketika beluk dimulai maka keluarlah satu atau dua orang pesilat yang mendemonstrasikan kebolehannya dalam bersilat.

5) Permainan debus, dua orang menggunakan peralatan debus, satu oranng memegang almadad ditempelkan di perut sang pemain dan satu orang lagi memegang pemukul atau gada yang siap dipukul ke almadad. 
6) Mengupas kelapa dengan menggunakan gigi, setelah kelapa dikupas lalu dipecahkan menggunakan kepala pemain debus.

7) Menggoreng kerupuk atau telur di atas kepala.

8) Membakar anggota tubuh dengan api dan menyisir rambut dengan api tanpa terbakar sedikitpun.

9) Menaiki anak tangga yang terbuat dari golok tajam.

10) Memakan pecahan kaca dan arang.

11) Gemrung, yaitu permainan instrument untuk mengakhiri pertunjukan.

Debus merupakan pertunjukan seni yang dilakukan secara berkelompok, biasanya dalam sebuah kelompok debus terdiri dari 12 sampai 15 orang yang masing-masing memiliki tugas, diantaranya:

1 orang juru kendang

1 orang penabuh terbang (rebana besar)

2 orang penabuh dogdog tingtit

1 orang penabuh kecrek

4 orang sebagai pendzikir

5 prang pemain debus

1 orang syaikh (guru/pemmimpin debus)

Dalam setiap penampilannya pemain dan pendukung debus menggunakan busana khas yang terlihat seperti busana yang dipakai oleh seorang pendekar. Busana yang digunakan dalam pertunjukan seni debus didominasi warna hitam yang terdiri dari:

1) Baju kampret yaitu baju tanpa kerah yang mempunyai kantong 2 buah dibagian bawah kiri dan kanan, serta bertangan panjang.

2) Celana pangsi yaitu celana yang dibuat tanpa ikat pinggang, bila dipakai digulung seperti memakai sarung dan baru diberi ikat pinggang. Ukuran bagian kaki cukup lebar untuk memudahkan bergerak dalam beratraksi.

3) Lomar (ikat kepala0 terbuat dari kain batik, berbentuk segi tiga atau segi empat yang dilipat menjadi segi tiga.

Pemain debus panjalu apabila dicermati mengandung nilai-nilai yang dapat dijadikan sebagai acuan dalam kehidupan bersama dan bekal kehidupan di kemudian hari. Nilai-nilai filosofis yang terkandung di dalamnya antara lan kerja sama, kerja keras, dan religius (Dinas Pendidikan dan Kebudayaan Kab. Ciamis, 2014: 218).

\section{Genjring Ronyok}

Genjring Ronyok adalah salah satu kesenian yan bernafaskan Islam. Hal ini dapat terlihat dari sejarah Genjring Ronyok yang menjadi salah satu media penyebaran agama Islam di Kawali pada 1842 seiring dengan masuknya tujuh ulama utusan dari kesultana Cirebon. Penyebaran agama pada masa itu memang dilakukan melalui media dakwah dan kesenian.

Genjring Ronyok pada awalnya dikenal dengan nama Genjring Buhun Tepak Lima. Nama tersbut doigunakan karena dalam kesenian ini menggunakan lima buah genjring, namun seiring dengan perkembangannya kesenian ini juga menampilkan sepuluh genjring dan satu bedug. Dari hal inilah maka nama Genjring Buhun Tepak Lima tidak digunakan lagi dan menjadi Genjring Ronyok. Adapun nama "ronyok" itu sendiri diambil dari cara penggunaan genjring yang dilakukan secara bersamaan dan berkumpul atau di dalam istilah bahasa Sunda dikenal dengan istilah dironyok.

Penyajian Genjring Ronyok menggabungkan dua unsure yaitu melodis dan ritmis. Unsur melodis terlihat pada vocal yang dilantunkan secara bersamaan dengan menggunakan iringan genjring, sdangkan unsure ritmis nampak pada alat musik yang digunakan yaitu perkusi. Penyajian vokal berupa lantunan sholawat yang berasal dari kitab Al-Barzanji yang berisi tentang kisah Nabi Muhammad SAW. Kesenian Genjring Ronyok biasa ditampilkan dalam acara keagamaan (maulid Nabi), acara perhelatan Kabupaten dan juga acara hajatan pernikahan maupun khitanan(Dinas Pendidikan dan Kebudayaan Kab. Ciamis, 2014: 223).

\section{Terebang}

Terebang adalah alat bunyi-bunyian yang terbuat dari kayu dengan muka bulat yang berkulit seperti rebana. Dibeberapa tempat di Jawa Barat kesenian Terebang dikenal dengan beberapa sebutan, sepertin terbang gede, terbang gedes, terbang ageung. 


\section{Potensi Budaya Kabupaten Ciamis Setelah Adanya Pemekaran Kabupaten Pangandaran dan Dampaknya Bagi Kabupaten Ciamis \\ 1. Potensi Budaya Kabupaten Ciamis Setelah Adanya Pemekaran Kabupaten Pangandaran}

Berdasarkan hasil wawancara peneliti dengan tokoh budayawan Kabupaten Ciamis yaitu Bapak Daday, peneliti ingin mengetahui lebih jauh bagaimana peran budayawan terhadap kesenian tradisional Kabupaten Ciamis setelah adanya pemekaran wilayah Pangandaran. Disini peneliti memfokuskan pada kesenian tradisional Ronggeng Gunung dan pariwisata yang notabene menjadi icon Kabupaten Ciamis. Menurut pak Daday, Ronggeng Gunung masih menjadi polemik di pemerintahan Kabupaten Ciamis, karena belum ada pembicaraan di pemerintahan terutama di komisi IV, jadi terlihat dengan kasat mata kebudayaan di Kabupaten Ciamis ini seolah-olah terabaikan. Bahkan dari pihak pemerintah belum ada yang mengajak para tokoh budayawan untuk duduk bersama membahas mengenai pengganti icon Kabupaten Ciamis seandainya Ronggeng Gunung diakui oleh Kabupaten Pangandaran. Bila melihat dari sejarahnya, kesenian Ronggeng Gunung masuk wilayah Kabupaten Pangandaran. Namun dalam hal pengembangannya, Ciamis berperan besar, sehingga masyarakat luas mengenal kesenian Ronggeng Gunung itu berasal dari Kabupaten Ciamis, bahkan sampai go Internasional diantaranya ke Singapura dan ke Jepang (hasil wawancara dengan Bapak Daday, 24 Januari 2016).

Kembali kepada permasalahan kesenian Ronggeng Gunung, bi Raspi yang merupakan tokoh legendaris kesenian Ronggeng Gunung berasal dari wilayah Banjarsari Kabupaten Ciamis. Ketika peneliti mewawancarai tokoh legendaris kesenian Ronggeng tersebut, beliau mengungkapkan mengenai silsilah atau garis keturunan Sang Dewi Siti Samboja perlu dicari fakta sejarah yang sebenarnya. Menurut cerita rakyat Dewi Siti Samboja adalah puteri Prabu Siliwangi ke 38 (Kusmayadi, 2012: 7). Hal ini sesuai dengan namanya karena berada di daerah pegunungan, baik kedudukan maupun tempat pementasannya berada didaerah pegunungan Kendeng yang membujur dari Selat Sunda sampai ke ujung Pananjung Pangandaran.

Waktu istirahat sang Dewi Siti Samboja ditanah pegunungan Kendeng tengah malam menerima wangsit dan mendengar suara yang mengabarkan bahwa demi keselamatan dirinya sang Dewi harus menyamar menjadi seorang penari Ronggeng dan menamai dirinya Nini Bogem/ nyi Rengganis dibimbing oleh Mama Lengser (Naya Dipa) sebagai penabuh. Tempat mulai berlatih adalah disatu goa yang pertama kali menjadi Ronggeng, maka tempat itu disebut Goa Panggung. Dari sinilah titik tolak Ronggeng Gunung. Dewi Siti Samboja atau Nini Bogem atau juga Nyi Rengganis dengan rombongannya melalui pengembaraan guna menyusun kekuatan dan mengumpulkan para pemuda disekitar pegunungan Kendeng dengan tujuan untuk menumpas para Bajak laut/ Bajo. Mengingat keadaan yang kurang menguntungkan, tujuan itu harus dirahasiakan. Maka secara hati-hati dan tersamar dalam gerakan tari-tarian Ronggeng Gunung dimasukkan unsur gerakan Penca Silat tanpa disadari oleh para pemuda tersebut. Rombongan Ronggeng Gunung dengan Nyi Rengganisnya sendiri yang berperan sebagai Ronggengnya.

Dalam melaksanakan kegiatannya yaitu pada waktu malam hari sebagai sarana hiburan pelepas lelah setelah para penduduk desa bekerja keras bercocok tanam.

Pada suatu malam ketika Rombongan mengadakan kegiatan pertunjukkan mereka kedatangan seorang pemuda yang belakangan diketahui adalah Patih Sawunggaling yang diutus oleh Sang Prabu tetapi tidak dipercaya, akhirnya terjadi pertempuran.

Karena ketangkasannya dalam berolah gerak dan tari maka ia memperliatkan kesaktiannya mengambil sapu lidi kemudian ditancapkannya pada sebuah batu dan batu tersebut muncul kedalam menyerupai alat kelamin laki-laki dan daerah tersebut sekarang disebut Paliken (Palakian).

Tidak henti-hentinya pasukan Bajak Laut menyerang datang ke satu daerah dan disana ada tiga pemuda yang bernama LabantakaSomanangga-Somananggi membantu Sawunggaling memperlihatkan kemampuannya sehingga Bajak Laut berkeliling di daerah panyutran (pamuteran).

Sawunggalilng diangkat sebagai Lurah Bujang (pemimpin). Secara diam-diam Sawunggaling berhasrat menikahi Nyi Rengganis. Mengetahui hal itu Sang Dewi mengajukan syarat. Ia bersedia dinikahi Sawunggaling asalkan ia sanggup menumpas para bajak laut/ bajo yang masih berkeliaran disekitar daerah Pananjung dan Sawunggaling menyanggupi syarat tersebut. 
Dari pegunungan Kendeng berangkatlah mereka menuju kerajaan Pananjung. Ditengah perjalanan mereka dihadang oleh para Bajo. Rupanya para Bajo mengetahui kehadiran Dewi Siti Samboja yang selama ini mereka cari-cari. Rombongan yang telah menyamar menjadi rombongan kesenian itu lalumenggelar pertunjukkan dan berusaha menyenangkan hati para Bajak Laut/ Bajo dengan menyuguhkan minuman keras berupa Tuak, bahkan diperkenankan untuk ikut menari.

Ketika para Bajo terlena karenamabuk minuman keras, kesempatan itu tidak disiasiakan. Mama lengser memeberi isyarat bagi para pengikutnya untuk segera bertindak menumpasnya. Namun kerena kesaktiannya tidak ada seorangpun para bajak laut/ bajo yang mati, bahkan akhirnya mereka menghilang. Konon tempat tersebut dikemudian hari dikenal dengan nama Bajolo (aya bagja Bajo ka olo) yang artinya tempat menghilangnya para Bajak Laut yang sakti.

Setelah pertempuran Sang Dewi kembali ke Pananjung dan menikah dengan Sawungguling yang kemudian memerintah Kerajaan Pananjung. Sebagai tanda peringatan Sang Dewi memberi nama sebuah Goa yang pernah dipergunakannya untuk meloloskan diri dari kejaran para Bajo yakni Goa Rengganis sedangkan sungai kecil yang mengalir disekitar Kerajaan Pananjung diberinama Cirengganis (Sejarah Singkat Ronggeng Gunung, 2014: 4).

\section{Dampak pemekaran Kabupaten Pangandaran terhadap potensi budaya dan pariwisata alam di Kabupaten Ciamis. \\ Berdasarkan hasil wawancara dengan}

Toto Marwoto, M.Pd Kadisdik Kabupaten Ciamis tanggal 3 Maret 2016menyatakan bahwa terlepasnya kabupaten Pangandaran tidak memberikan dampak yang begitu mendasar bagi potensi budaya yang terdapat di kabupaten Ciamis. Salah satunya Ronggeng Gunung yang kini menjadi perdebatan mengenai kepemilikannya, apakah masuk kabupaten Pangandaran atau masih tetap menjadi bagian dari kabupaten Ciamis. Dalam hal ini Kadisdikbud kabupaten Ciamis memberikan tanggapan bahwa Ronggeng Gunung tidak perlu diperebutkan, karena budaya merupakan kekayaan nasional dan masalah kepemilikan tergantung dari lisensinya. Kadisdikbud kabupaten Ciamis menyatakan bahwa budaya tidak tersekat oleh unsur kedaerahan, apalagi kabupaten Ciamis, kabupaten Pangandaran, dan kota Banjar adalah masih satu rumpun yang dulunya pernah menjadi bagian dari kabupaten Ciamis. Justru dengan adanya pemekaran ini masyarakat harus bisa mencari dan mengkaji nilai-nilai yang terdapat dalam kesenian Ronggeng Gunung, seperti nilai kerjasama, ksatria, dan sebagainya, sehingga dari nilai-nilai tersebut masyarakat akan lebih memahami arti dari sebuah kebudayaan. Apalagi dalam kurikulum pendidikan di sekolah-sekolah sudah ada muatan lokalnya.

Sedangkan pendapat Komisi IV DPRD Ciamis, Hendra Markusi,... menyatakan bahwa kesenian Ronggeng Gunung belum bisa dikatakan milik kabupaten Ciamis ataupun kabupaten Pangandaran. Dalam hal ini pemerintah kabupaten Ciamis akan mengeluarkan Perda tentang kebudayaan, seperti Situ Lengkong Panjalu, Kampung Kuta, danaudanau yang terdapat di kabupaten Ciamis, dan situs-situs yang ada di Kabupaten Ciamis. Asetaset yang terdapat di kabupaten Ciamis ini akan digali semua. Kemudian dibidang pendidikan disambungkan dengan muatan lokal, sehingga di sekolah-sekolah siswa akan lebih memahami tentang kekayaan daerahnya masing-masing (Hasil wawancara dengan Komisi IV DPRD Kab. Ciamis, tanggal 3 Maret 2016). Selanjutnya, berdasarkan hasil wawancara dengan Kabid Destinasi Wisata, Dinas Pariwisata dan Ekonomi Kreatif Kab. Ciamis yaitu Budi Kurnia menyatakan bahwa dengan adanya pemekaran kabupaten Pangandaran menimbulkan dampak yang begitu besar bagi PAD (Pendapatan Asli Daerah) kabupaten Ciamis, yaitu $85 \%$ PAD pariwisata hilang dan kalau diuangkan mencapai 6 miliar. Sehingga, untuk menanggapi hal tersebut kabupaten Ciamis harus secepatnya harus menentukan karakteristik wisata yang akan dikembangkan. Secara teknis ada enam titik rintisan pengembangan potensi budaya dan pariwisata alam di kabupaten Ciamis dan diharapkan bisa menmbah PAD kabupaten Ciamis., yaitu:

1) Situs Karangkamulyan

2) Situs Gunung Sususru

3) Situs Kawali (Astana Gede)

4) Panjalu (Situ Lengkong)

5) Situ Wangi

6) Wisata Tirta

Untuk permasalahan kesenian Ronggeng Gunung yang kini menjadi perebutan antara kabupaten Ciamis dan kabupaten Pangnadaran Budi Kurnia menyatakan hal tersebut tidak usah 
diperebutkan biarkanlah menjadi milik kabupaten Ciamis dan kabupaten Pangandaran, karena dahulunya dua kabupaten ini lahir dari rumpun yang sama.

\section{PENUTUP}

\section{Simpulan}

Potensi budaya dan pariwisata alam kabupaten Ciamis sebelum terjadinya pemekaran kabupaten Pangandaran yaitu, ronggeng gunung, Bebegig Sukamantri, ronggeng amen, debus Panjalu, wayang landung, dan sebagainya. Sedangkan untuk pariwisata alam yang memberikan pemasukan paling besar bagi PAD kabupaten Ciamis adalah wisata alam pantai Pangandaran.

Potensi budaya dan pariwisata alam kabupaten Ciamis setelah terjadinya pemekaran kabupaten Pangandaran mengalami perubahan, yaitu belum jelasnya kesenian ronggeng gunung dalam hal kepemilikan, apakah menjadi bagian dari kabupaten Ciamis atau bagian kabupaten Pangandaran. Namun pihak pemerintah kabupaten Ciamis berharap hal ini tidak menjadi rebutan justru kesenian ronggeng gunung menjadi milik bersama, karena kabupaten Ciamis dan kabupaten Pangandaran merupakan satu rumpun. Sedangkan untuk pariwisata alam, kabupaten Ciamis kehilangan wisata alam pantai Pangandaran yang memberikan pemasukan paling besarbagi PAD kabupaten Ciamis.

Dampak pemekaran kabupaten Pangandaran bagi potensi budaya yang ada di kabupaten Ciamis tidak memberikan dampak yang begitu besar, karena kesenian ronggeng gunung yang kini masih belum ditentukan menjadi milik siapa, bagi pemerintah kabupaten Ciamis bukan hal yang harus diperdebatkan, tapi kesenian ini menjadi milik bersama antara kabupaten Ciamis dan kabupaten Pangandaran. Sedangkan, dampak pemekaran kabupaten Pangandaran yang paling besar dirasakan adalah dalam hal pariwisata alam, karena dengan terlepasnya Pangandaran, kabupaten Ciamiskehilangan PAD sampai $85 \%$ dan kalau diuangkan mencapai 6 miliar.

\section{DAFTAR PUSTAKA}

BPS Kabupaten Ciamis, 2013. Data Statistik Kabupaten Ciamis.
Creswell, J.W. (1998). Qualitative inquiry and research design: choosing among five tradition. London: Sage Publication.

Cresswell, John W. 2010. Research Design: Pendekatan Kualitatif, Kuantitatif dan Mixed, terj. Ahmad Fawaid. Yogyakarta: Pustaka Pelajar.

Departemen Pendidikan dan Kebudayaan, 1996.

Dinas Pendidikan dan Kebudayaan Kabupaten Ciamis. 2014. Kabupaten Ciamis Dalam Sudut Pandang Sejarah dan Nilai Budaya.

Haviland. 1999. Antropologi Jilid 1. PT GeloraAsmara Pratama: Surakarta.

Hopkins, D. (1993). A Teachers Guide to Classroom Research. Buckingham: Open Univercity.

Ismawati, Esti. 2000. Metode Penelitian Pendidikan Bahasa dan Sastra. Surakarta: Yuma Pustaka.

Kalangie, NS. 1994. Kebudayaan dan Kesehatan (Pengembangan Pelayanan Kesehatan Primer Melalui Pendekatan Sosial Budaya). Jakarta: Kesaint BlancIndah Corp.

Koentiaraningrat. 1996. Pengantar Ilmu Antropologi. Jakarta: Rineka Cipta.

Kuswandi. 2011. Integrasi Budaya Pada Tata Ruang Arsitektur Dalam Masyarakat Sunda. Penelitian LPPM Universitas Galuh Ciamis.

Kusmayadi, Nesri. 2007. Sejarah Singkat Ronggeng Gunung. Jakarta: PT. Pustaka Gramedia Utama.

Kompas, 26 Agustus 2010. Sejarah Singkat Ronggeng Gunung. Kompas Press.

Lincoln and Guba. (1985). Naturalistic Inquiry, London: Sage Publication Beverly Hill.

Miles, MB., Huberman, M. (1984). Qualitative Data Analysis: A Sourcebook of New Methods. London: Sage Publication, Inc.

Moleong, L.J. (1995). Metodologi Penelitian Kualitatif,i. Bandung: PT. Remaja Rosdakarya.

Mulyana, Deddy. (2010). Metode Penelitian Kualitatif. Jakarta: Rosda.

PP No. 28 tahun 2008. Tentang Pengenaan Sanksi Administrasi Berupa Denda Dibidang Kepabeaan.

Sugiyono. (2012). Metode Penelitian Kuantitatif, Kualitatif, dan $R \& D$. Bandung: Alfabeta.

Sukidin, 2005. Pengantar Antropologi. Bandung: Rineka.

Stockdale, Jhon Joseph. 2010. Eksotisme Jawa: Ragam Kehidupan dan Kebudayaan 
Wulan Sondarika, Dewi Ratih, \& Aan Suryana

Dampak Pemekaran Kabupaten Pangandaran Terhadap Potensi Budaya dan Pariwisata Alam Kabupaten Ciamis

Masyarakat Jawa. Yogyakarta: Progresif

Book. 
Jurnal Artefak: History and Education, Vol.4 No.1 April 2017 